\title{
A STUDY TO ESTIMATE SUBCLINICAL ATHEROSCLEROSIS IN PATIENTS WITH TYPE 2 DIABETES MELLITUS BY MEASURING THE CAROTID INTIMAL MEDIAL THICKNESS
}

\author{
Natarajan Kandasamy1, Rajan Ganesan², Thilakavathi Rajendiran ${ }^{3}$, Ayyappan ${ }^{4}$, Archana Balakrishnan Mani ${ }^{5}$, \\ Arungandhi Pachaippan 6 \\ 1 Professor, Department of Medicine, Government Stanley Medical College, Chennai. \\ 2Professor, Department of Medicine, Government Stanley Medical College, Chennai. \\ ${ }^{3}$ Assistant Professor, Department of Medicine, Government Stanley Medical College, Chennai. \\ ${ }^{4}$ Postgraduate, Department of Medicine, Government Stanley Medical College, Chennai. \\ 5 Postgraduate, Department of Medicine, Government Stanley Medical College, Chennai. \\ ${ }^{6}$ Postgraduate, Department of Medicine, Government Stanley Medical College, Chennai.
}

\begin{abstract}
\section{BACKGROUND}

Atherosclerosis is a leading cause of mortality in developed and developing nations. It forms the major determinant in the reduction of volume of vascular lumen in various parts of the blood vessel. Atherosclerosis and diabetes mellitus has major relations. Diabetic population is expected to reach an epidemic proportion not only in India but in many countries around the world which in turn has greatly accelerated the risk for cardiovascular diseases and early mortality. In another two decades, cardiovascular diseases complicated by atherosclerosis will be the major cause of death. Carotid intimal medial thickness measurement can serve as an early predictor of subclinical atherosclerosis. The purpose of this study was to evaluate the usefulness of measuring Carotid intimal medial thickness (CIMT) in predicting the subclinical atherosclerosis.
\end{abstract}

\section{AIMS AND OBJECTIVES}

To estimate subclinical atherosclerosis in patients with type 2 diabetes mellitus by measuring the carotid intimal medial thickness. To study the association of age, sex, body mass index, smoking, alcohol, duration of diabetes, hypertension, fasting hyperglycaemia, serum total cholesterol with the carotid intimal medial thickness.

\section{MATERIALS AND METHODS}

This study was carried out in a tertiary care hospital over a period of 6 months after obtaining Institutional Ethical Committee approval. Fifty patients who presented with history of type 2 diabetes mellitus (diagnosed according to the ADA 2014 criteria) to OPDs and admitted in wards and who fulfilled the inclusion criteria were included in the study. Patients were subjected to symptom analysis, clinical examination, BP recording in all 4 limbs, examination of all peripheral pulses, height and weight and BMI calculation. Baseline laboratory investigations, resting 12-lead ECG, and CIMT measurement by ultrasonographic scanning were done for each patient. All these findings were assessed using appropriate statistical methods.

\section{RESULTS}

The study revealed that even in the absence of smoking and alcohol, normotension and normal lipid profile, an increase in the duration of diabetes, altered fasting and postprandial glycaemic status can lead to CIMT $>0.9$ which is a marker of increased risk for atherosclerosis.

\section{CONCLUSION}

CIMT greater than $0.9 \mathrm{~mm}$ is an individual marker of generalised atherosclerosis. Patients with these values are at higher risk for future cardiovascular events and newer or recurrent ischaemic strokes. Measuring CIMT values in all diabetics can predict the risk of developing atherosclerosis related adverse events and better control of diabetes mellitus can aid in achieving regression of CIMT.

\section{KEYWORDS}

Carotid Intimal Medial Thickness, Type 2 Diabetes Mellitus, Subclinical Atherosclerosis.

HOW TO CITE THIS ARTICLE: Kandasamy N, Ganesan R, Rajendiran T, et al. A study to estimate subclinical atherosclerosis in patients with type 2 diabetes mellitus by measuring the carotid intimal medial thickness. J. Evolution Med. Dent. Sci. 2016;5(73): 5370-5377, DOI: $10.14260 /$ jemds/2016/1219

Financial or Other, Competing Interest: None.

Submission 22-07-2016, Peer Review 31-08-2016,

Acceptance 06-09-2016, Published 12-09-2016.

Corresponding Author:

Dr. Natarajan Kandasamy,

Oak 39, Ben Foundations, Maple Orchard,

Padikuppam Road, Anna Nagar West,

Chennai-600040.

E-mail: archana.vmc@gmail.com,nnatarajan72@yahoo.com

DOI: $10.14260 /$ jemds/2016/1219

\section{INTRODUCTION}

Atherosclerosis is a leading cause of mortality in developed and developing nations. It forms the major determinant in the reduction of volume of vascular lumen in various parts of the blood vessel. Atherosclerosis and diabetes mellitus have major relations. Diabetic population is expected to reach an epidemic proportion not only in India but in many countries around the world which in turn has greatly accelerated the risk for cardiovascular diseases and early mortality. 
In another two decades, cardiovascular diseases complicated by atherosclerosis will be the major cause of death. Carotid intimal medial thickness measurement can serve as an early predictor of subclinical atherosclerosis.(1) The purpose of this study was to evaluate the usefulness of measuring Carotid intimal medial thickness (CIMT) in predicting the subclinical atherosclerosis.

\section{AIMS AND OBJECTIVES}

- To estimate subclinical atherosclerosis in patients with type 2 diabetes mellitus by measuring the carotid intimal medial thickness.

- To study the association of age, sex, body mass index, smoking, alcohol, duration of diabetes, hypertension, fasting hyperglycaemia, serum total cholesterol with the carotid intimal medial thickness.

\section{MATERIALS AND METHODS}

This study was carried out in a tertiary care hospital over a period of 6 months after obtaining Institutional Ethical Committee approval. This study was a prospective, observational study. In this study, fifty patients with history of type 2 diabetes mellitus (diagnosed according to the ADA 2014 criteria) after 30 years of age who presented to OPDs and admitted in wards were included in the study. Patients who presented with acute metabolic complications like hypoglycaemia, diabetic ketoacidosis, hyperosmolar hyperglycaemic state, cerebrovascular accidents, acute infections and deranged liver functions were excluded from the study.

Patients who had inherited disorders of lipid and lipoprotein metabolism and/or family history of such disorders were not included. Patients who were on lipid lowering treatment, patients with history of CABG or PCI intervention, Hypertensive patients, patients aged more than 60 years and patients with signs and symptoms of CHD/cerebrovascular disease were excluded. Those patients who were included in the study were subjected to symptom analysis and clinical examination. BP was recorded in all 4 limbs with a standard mercury sphygmomanometer. Hypertension was defined in accordance with JNC VIII criteria as a systolic blood pressure $>140 \mathrm{mmHg}$ and a diastolic blood pressure $>90 \mathrm{mmHg}$. All peripheral pulses were examined and height, weight and BMI were calculated. Serum total cholesterol, serum creatinine, blood urea, and blood sugar results were obtained by analysing fasting blood sample.

Hyperlipidaemia was considered to be present when the patient had a serum total cholesterol level $>200 \mathrm{mg} / \mathrm{dL}$. In addition to the basic laboratory investigations, resting 12-lead ECG and CIMT measurement were done for each patient. CIMT measurement was obtained by performing ultrasonographic scanning of the carotid arteries using Esaote-scanner with a linear transducer (high frequency range 10 to $12 \mathrm{MHz}$ ). CIMT was assessed at about $1.0 \mathrm{~cm}$ proximal to the carotid bulb. Carotid IMT was measured on both sides and the average value is taken as the mean CIMT. CIMT value of more than $0.9 \mathrm{~mm}$ is suggestive of significant atherosclerosis. All these findings were assessed using appropriate statistical methods.

\section{STATISTICAL ANALYSIS AND INFERENCE}

Descriptive statistics were done for all data and were reported in terms of mean values and percentages.
Suitable statistical tests of comparison were done. Continuous variables were analysed with the unpaired t test. Categorical variables were analysed with the Chi-Square Test and Fisher Exact Test. Statistical significance was taken as $\mathrm{P}$ $<0.05$. The data was analysed using SPSS version 16 and Microsoft Excel 2007.

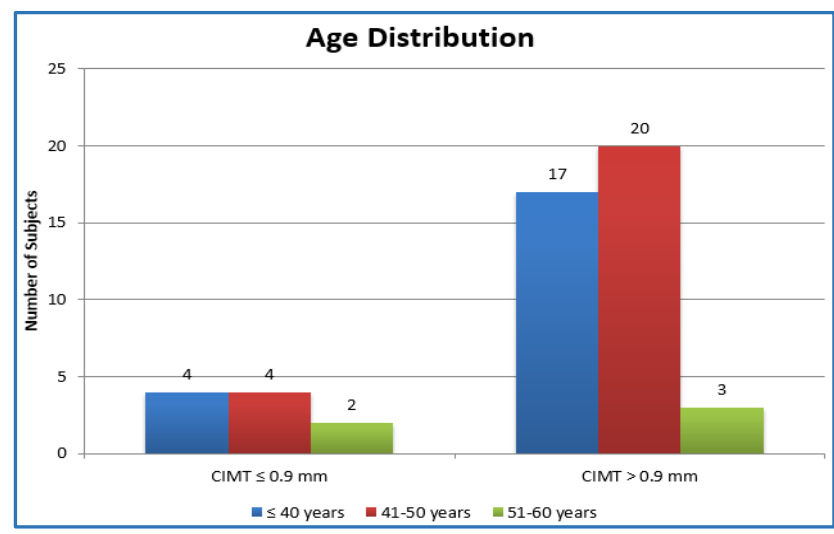

Fig. 1: Bar Diagram Representing the Age distribution and their CIMT among the study Population

\begin{tabular}{|c|c|c|c|c|}
\hline $\begin{array}{c}\text { Age } \\
\text { Distribution }\end{array}$ & $\begin{array}{c}\text { CIMT } \leq \\
\mathbf{0 . 9} \mathbf{~ m m}\end{array}$ & $\%$ & $\begin{array}{c}\text { CIMT > } \\
\mathbf{0 . 9} \mathbf{~ m m}\end{array}$ & $\%$ \\
\hline$\leq 40$ years & 4 & 40.00 & 17 & 42.50 \\
\hline 41-50 years & 4 & 40.00 & 20 & 50.00 \\
\hline 51-60 years & 2 & 20.00 & 3 & 7.50 \\
\hline Total & 10 & 100 & 40 & 100 \\
\hline Table 1: Table Representing the Age distribution and \\
their CIMT among the Study Population \\
\hline
\end{tabular}

\begin{tabular}{|c|c|c|}
\hline Age Distribution & CIMT $\mathbf{5 0 . 9} \mathbf{~ m m}$ & CIMT $>\mathbf{0 . 9} \mathbf{~ m m}$ \\
\hline N & 10 & 40 \\
\hline Mean & 44.40 & 43.48 \\
\hline SD & 6.95 & 5.90 \\
\hline \multicolumn{2}{|c|}{ P value Unpaired t Test } & 0.7049 \\
\hline \multicolumn{2}{|c|}{ Table 2: Statistics of CIMT among the Study Population } \\
\hline
\end{tabular}

Majority of the CIMT $\leq 0.9 \mathrm{~mm}$ Group patients belonged to the 41-50 years age class interval $(n=4,40 \%)$ with a mean age of 44.40 years. In the CIMT $>0.9 \mathrm{~mm}$ group patients, majority belonged to the same age class interval $(n=20,50 \%)$ with a mean age of 43.48 years. The association between the study groups and age distribution is considered to be not statistically significant since $\mathrm{p}>0.05$ as per unpaired $t$ test.

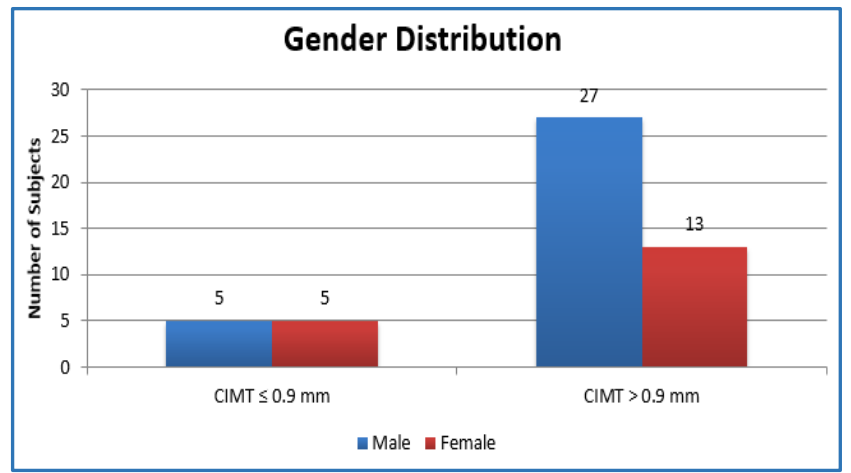

Fig. 2: Bar Diagram representing the Gender Distribution and their CIMT among the Study Population 


\begin{tabular}{|c|c|c|c|c|}
\hline $\begin{array}{c}\text { Gender } \\
\text { Distribution }\end{array}$ & $\begin{array}{c}\text { CIMT } \leq \\
\mathbf{0 . 9} \mathbf{~ m m}\end{array}$ & $\mathbf{\%}$ & $\begin{array}{c}\text { CIMT > } \\
\mathbf{0 . 9} \mathbf{~ m m}\end{array}$ & $\mathbf{\%}$ \\
\hline Male & 5 & 50.00 & 27 & 67.50 \\
\hline Female & 5 & 50.00 & 13 & 32.50 \\
\hline Total & $\mathbf{1 0}$ & $\mathbf{1 0 0}$ & $\mathbf{4 0}$ & $\mathbf{1 0 0}$ \\
\hline P value Fishers Exact Test & \multicolumn{2}{|c|}{0.4627} \\
\hline Table 3: Table representing the Gender distribution and \\
their CIMT among the Study Population \\
\hline
\end{tabular}

Majority of the CIMT $\leq 0.9 \mathrm{~mm}$ group patients belonged to the male gender class interval $(n=5,50 \%)$. In the CIMT $>0.9$ mm group patients, majority also belonged to the male gender class interval $(n=27,67.50 \%)$. The association between the study groups and gender distribution is considered to be not statistically significant since $p>0.05$ as per Fisher's exact test.

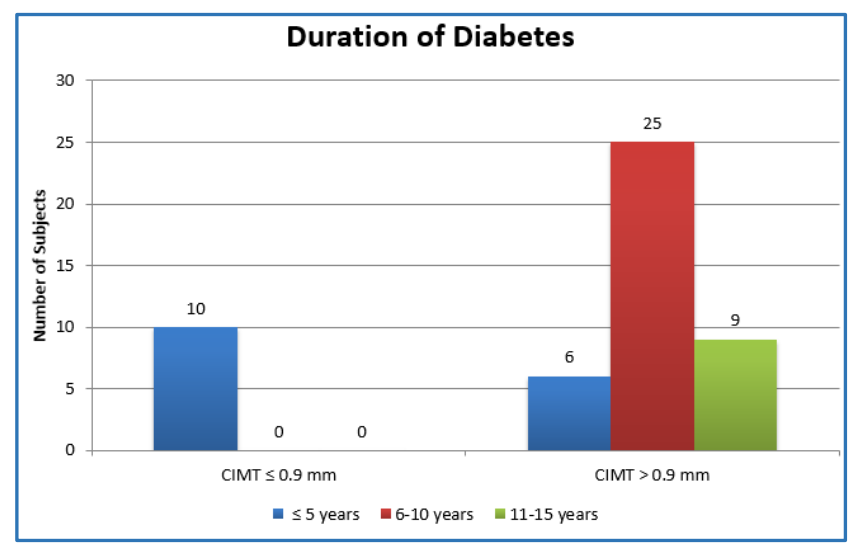

Fig. 3: Bar Diagram representing the duration of Diabetes and their CIMT among the Study Population

\begin{tabular}{|c|c|c|c|c|}
\hline $\begin{array}{c}\text { Duration of } \\
\text { Diabetes }\end{array}$ & $\begin{array}{c}\text { CIMT } \leq \\
\mathbf{0 . 9} \mathbf{~ m m}\end{array}$ & $\mathbf{\%}$ & $\begin{array}{c}\text { CIMT }> \\
\mathbf{0 . 9} \mathbf{~ m m}\end{array}$ & $\mathbf{\%}$ \\
\hline$\leq 5$ years & 10 & 100.00 & 6 & 15.00 \\
\hline 6-10 years & 0 & 0.00 & 25 & 62.50 \\
\hline 11-15 years & 0 & 0.00 & 9 & 22.50 \\
\hline Total & $\mathbf{1 0}$ & $\mathbf{1 0 0}$ & $\mathbf{4 0}$ & $\mathbf{1 0 0}$ \\
\hline
\end{tabular}

Table 4: Table Correlating the duration of Diabetes and their CIMT among the Study Population

\begin{tabular}{|c|c|c|}
\hline $\begin{array}{c}\text { Duration of } \\
\text { Diabetes }\end{array}$ & $\begin{array}{c}\text { CIMT } \leq \mathbf{0 . 9} \\
\mathbf{~ m m}\end{array}$ & $\begin{array}{c}\text { CIMT }>\mathbf{0 . 9} \\
\mathbf{~ m m}\end{array}$ \\
\hline N & 10 & 40 \\
\hline Mean & 2.40 & 8.90 \\
\hline SD & 0.84 & 3.25 \\
\hline P value Unpaired t Test & 0.0000 \\
\hline Table 5: Statistics of CIMT among the Study Population \\
\hline
\end{tabular}

\section{RESULTS}

In patients belonging to $\mathrm{CIMT} \leq 0.9 \mathrm{~mm}$ group, the mean duration of diabetes is 2.40 years. In CIMT $>0.9 \mathrm{~mm}$ group, the mean duration of diabetes is 8.90 years. The decreased mean duration of diabetes in CIMT $\leq 0.9 \mathrm{~mm}$ group compared to the CIMT $>0.9 \mathrm{~mm}$ group is statistically significant as the $p$ value is 0.0000 as per unpaired t-test indicating a true difference among study groups. The mean duration of diabetes was meaningfully less in CIMT $\leq 0.9 \mathrm{~mm}$ group compared to the CIMT $>0.9 \mathrm{~mm}$ group by 6.50 years. This significant difference of $73 \%$ decrease in mean duration of diabetes in CIMT $\leq 0.9 \mathrm{~mm}$ group compared to the CIMT $>0.9 \mathrm{~mm}$ group is true and has not occurred by chance. In this study, we can safely conclude that mean duration of diabetes was significantly and consistently higher in CIMT $>0.9 \mathrm{~mm}$ group compared to the CIMT $\leq 0.9 \mathrm{~mm}$ group. Hence, we can infer that the incidence of CIMT $>0.9 \mathrm{~mm}$ increases with increasing duration of diabetes.

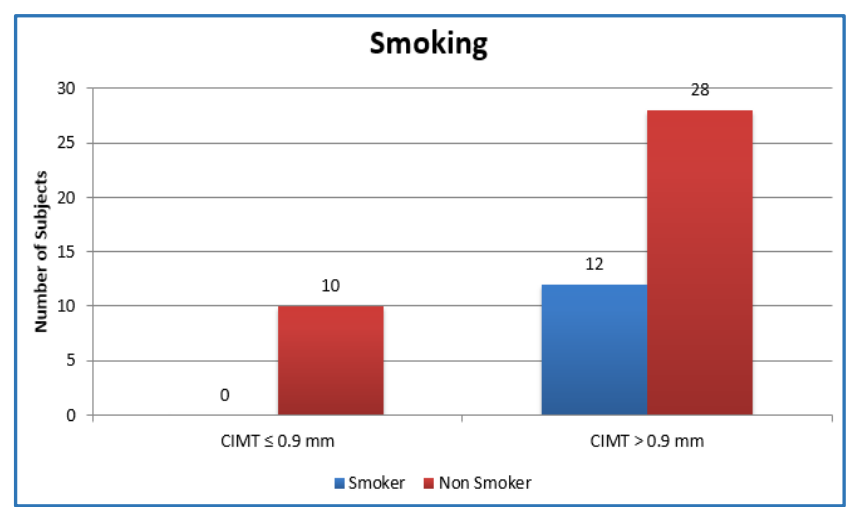

Fig. 4: Bar Diagram depicting the trend of Smoking and their CIMT among the Study Population

\begin{tabular}{|c|c|c|c|c|}
\hline Smoking & $\begin{array}{c}\text { CIMT } \leq \mathbf{0 . 9} \\
\mathbf{m m}\end{array}$ & $\mathbf{\%}$ & $\begin{array}{c}\text { CIMT > 0.9 } \\
\mathbf{m m}\end{array}$ & $\mathbf{\%}$ \\
\hline Smoker & 0 & 0.00 & 12 & 30.00 \\
\hline $\begin{array}{c}\text { Non- } \\
\text { Smoker }\end{array}$ & 10 & $\begin{array}{c}100.0 \\
0\end{array}$ & 28 & 70.00 \\
\hline Total & $\mathbf{1 0}$ & $\mathbf{1 0 0}$ & $\mathbf{4 0}$ & $\mathbf{1 0 0}$ \\
\hline \multicolumn{4}{|c|}{ P value Fisher's Exact Test } & $\mathbf{0 . 0 3 2 0}$ \\
\hline $\begin{array}{r}\text { Table 6: Table representing the trend of Smoking and } \\
\text { their CIMT among the Study Population }\end{array}$ \\
\hline
\end{tabular}

\section{RESULTS}

In patients belonging to CIMT $\leq 0.9 \mathrm{~mm}$ group, majority were non-smokers ( $\mathrm{n}=10,100 \%)$. In CIMT $>0.9 \mathrm{~mm}$ group, majority too were non-smokers $(n=28,70 \%)$. The increased incidence of smoking in CIMT $>0.9 \mathrm{~mm}$ group compared to the CIMT $\leq 0.9$ $\mathrm{mm}$ group is statistically significant as the $p$ value is 0.0320 as per Fisher's exact test indicating a true difference among study groups. The incidence of smoking was meaningfully more in CIMT $>0.9 \mathrm{~mm}$ group compared to the CIMT $\leq 0.9 \mathrm{~mm}$ group by 30 percentage points. This significant difference of 1.43 times increase in incidence of smoking in CIMT $>0.9 \mathrm{~mm}$ group compared to the CIMT $\leq 0.9 \mathrm{~mm}$ group is true and has not occurred by chance. In this study, we can safely conclude that incidence of smoking was significantly and consistently higher in CIMT $>0.9 \mathrm{~mm}$ group compared to the CIMT $\leq 0.9 \mathrm{~mm}$ group. Hence, we can infer that the incidence of CIMT $>0.9 \mathrm{~mm}$ increases among smokers.

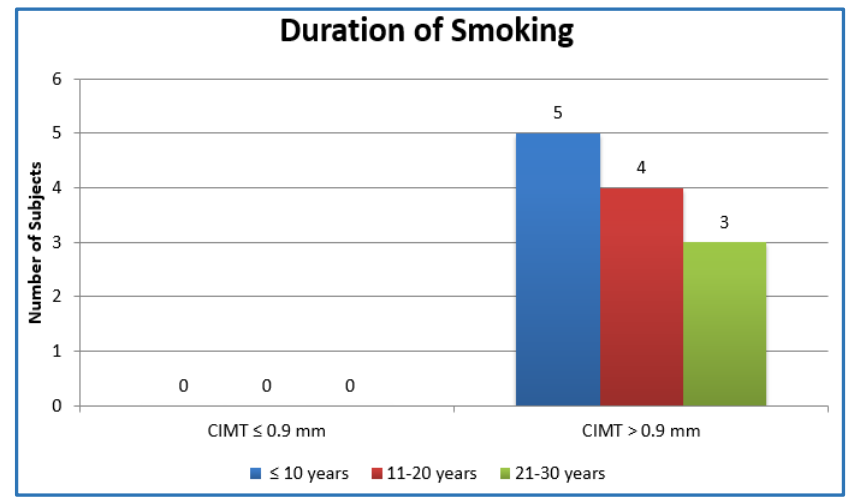

Fig. 5: Bar Diagram correlating the Duration of Smoking and CIMT among the Study Population 


\begin{tabular}{|c|c|c|c|c|}
\hline $\begin{array}{c}\text { Duration of } \\
\text { Smoking }\end{array}$ & $\begin{array}{c}\text { CIMT } \leq \\
\mathbf{0 . 9} \mathbf{~ m m}\end{array}$ & $\mathbf{\%}$ & $\begin{array}{c}\text { CIMT > } \\
\mathbf{0 . 9} \mathbf{~ m m}\end{array}$ & $\mathbf{\%}$ \\
\hline$\leq 10$ years & 0 & 0.00 & 5 & 12.50 \\
\hline 11-20 years & 0 & 0.00 & 4 & 10.00 \\
\hline $21-30$ years & 0 & 0.00 & 3 & 7.50 \\
\hline Total & 0 & 0 & 12 & 30 \\
\hline $\begin{array}{r}\text { Table 7: Table Correlating the duration of Smoking and } \\
\text { CIMT among the Study Population }\end{array}$ \\
\hline
\end{tabular}

\begin{tabular}{|c|c|c|}
\hline $\begin{array}{c}\text { Duration of } \\
\text { Smoking }\end{array}$ & CIMT $\leq \mathbf{0 . 9} \mathbf{~ m m}$ & CIMT $>\mathbf{0 . 9} \mathbf{~ m m}$ \\
\hline N & 0 & 12 \\
\hline Mean & 0.00 & 16.25 \\
\hline SD & 0.00 & 7.72 \\
\hline \multicolumn{2}{|c|}{ P value Unpaired t Test } & NA \\
\hline \multicolumn{2}{|c|}{$\begin{array}{c}\text { Table 8: Statistics of duration of Smoking and CIMT } \\
\text { among the Study Population }\end{array}$} \\
\hline
\end{tabular}

By conventional criteria, the association between the study groups and duration of smoking is considered to be not statistically significant since $\mathrm{p}>0.05$.

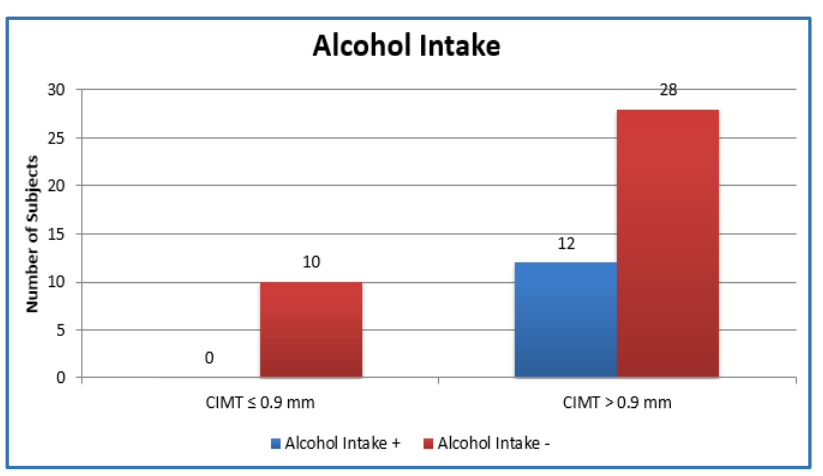

Fig. 6: Bar Diagram representing the trend of Alcohol Intake in relation with CIMT among the Study Population

\begin{tabular}{|c|c|c|c|c|}
\hline Alcohol Intake & $\begin{array}{c}\text { CIMT } \leq \\
\mathbf{0 . 9} \mathbf{~ m m}\end{array}$ & $\mathbf{\%}$ & $\begin{array}{c}\text { CIMT > } \\
\mathbf{0 . 9} \mathbf{~ m m}\end{array}$ & $\%$ \\
\hline Alcohol Intake + & 0 & 0.00 & 12 & 30.00 \\
\hline Alcohol Intake - & 10 & 100.00 & 28 & 70.00 \\
\hline Total & $\mathbf{1 0}$ & $\mathbf{1 0 0}$ & $\mathbf{4 0}$ & $\mathbf{1 0 0}$ \\
\hline P value Fishers Exact Test & \multicolumn{2}{|c|}{0.0420} \\
\hline Table 9: Statistical Table representing the trend of \\
Alcohol Intake in relation with CIMT among the Study \\
Population
\end{tabular}

\section{RESULTS}

In patients belonging to $\mathrm{CIMT} \leq 0.9 \mathrm{~mm}$ group, majority were non-alcoholics $(\mathrm{n}=10,100 \%)$. In CIMT $>0.9 \mathrm{~mm}$ group, majority too were non-alcoholics $(n=28,70 \%)$. The increased incidence of alcohol intake in CIMT $>0.9 \mathrm{~mm}$ group compared to the CIMT $\leq 0.9 \mathrm{~mm}$ group is statistically significant as the $p$ value is 0.0420 as per Fisher's exact test indicating a true difference among study groups. The incidence of alcohol was meaningfully more in CIMT $>0.9 \mathrm{~mm}$ group compared to the CIMT $\leq 0.9 \mathrm{~mm}$ group by 30 percentage points. This significant difference of 1.43 times increase in incidence of alcohol intake in CIMT $>0.9 \mathrm{~mm}$ group compared to the CIMT $\leq 0.9 \mathrm{~mm}$ group is true and has not occurred by chance. In this study, we can safely conclude that incidence of alcohol intake was significantly and consistently higher in CIMT $>0.9 \mathrm{~mm}$ group compared to the CIMT $\leq 0.9 \mathrm{~mm}$ group. Hence, we can infer that the incidence of CIMT $>0.9 \mathrm{~mm}$ increases among subjects with the habit of alcohol intake.

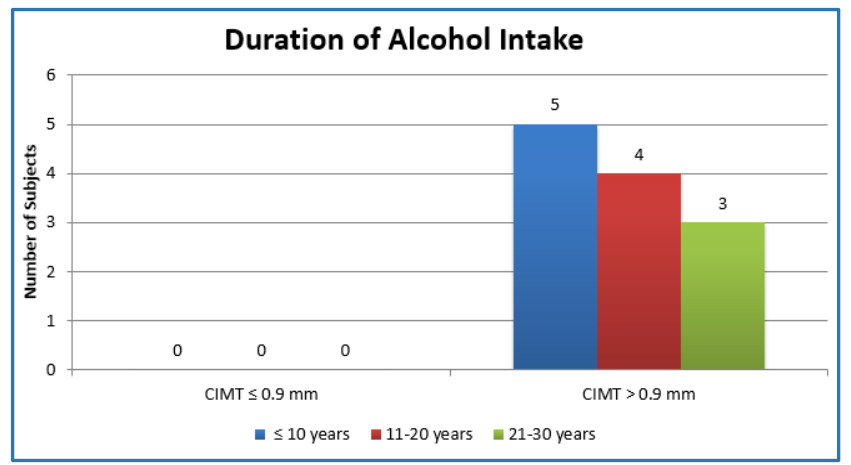

Fig. 7: Bar Diagram representing the duration of Alcohol intake in relation to CIMT among the Study Population

\begin{tabular}{|c|c|c|c|c|}
\hline $\begin{array}{c}\text { Duration of } \\
\text { Alcohol Intake }\end{array}$ & $\begin{array}{c}\text { CIMT } \leq \\
\mathbf{0 . 9} \mathbf{~ m m}\end{array}$ & $\mathbf{\%}$ & $\begin{array}{c}\text { CIMT > } \\
\mathbf{0 . 9} \mathbf{~ m m}\end{array}$ & $\mathbf{\%}$ \\
\hline$\leq 10$ years & 0 & 0.00 & 5 & 12.50 \\
\hline $11-20$ years & 0 & 0.00 & 4 & 10.00 \\
\hline $21-30$ years & 0 & 0.00 & 3 & 7.50 \\
\hline Total & $\mathbf{0}$ & $\mathbf{0}$ & $\mathbf{1 2}$ & $\mathbf{3 0}$ \\
\hline $\begin{array}{c}\text { Table 10: Table representing the duration of Alcohol } \\
\text { intake in relation to CIMT among the Study Population }\end{array}$ \\
\hline
\end{tabular}

\begin{tabular}{|c|c|c|}
\hline $\begin{array}{c}\text { Duration of } \\
\text { Alcohol Intake }\end{array}$ & CIMT $\mathbf{5 0 . 9} \mathbf{~ m m}$ & CIMT $>\mathbf{0 . 9} \mathbf{~ m m}$ \\
\hline $\mathrm{N}$ & 0 & 12 \\
\hline Mean & 0.00 & 16.25 \\
\hline SD & 0.00 & 7.83 \\
\hline \multicolumn{2}{|c|}{ P value Unpaired t Test } & NA \\
\hline
\end{tabular}

Table 11: Statistics representing the duration of Alcohol intake in relation to CIMT among the Study Population

By conventional criteria, the association between the study groups and duration of alcohol intake is considered to be not statistically significant since $\mathrm{p}>0.05$.

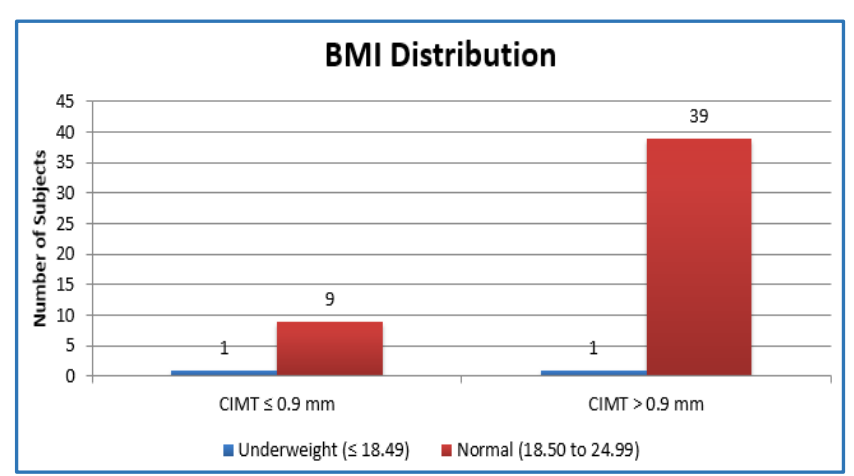

Fig. 8: Bar Diagram representing the BMI Distribution in relation to CIMT among the Study Population

\begin{tabular}{|c|c|c|c|c|}
\hline $\begin{array}{c}\text { BMI } \\
\text { Distribution }\end{array}$ & $\begin{array}{c}\text { CIMT } \leq \\
\mathbf{0 . 9} \mathbf{~ m m}\end{array}$ & $\mathbf{\%}$ & $\begin{array}{c}\text { CIMT }> \\
\mathbf{0 . 9} \mathbf{~ m m}\end{array}$ & $\mathbf{\%}$ \\
\hline $\begin{array}{c}\text { Underweight }(\leq \\
\text { 18.49) }\end{array}$ & 1 & 10.00 & 1 & 2.50 \\
\hline $\begin{array}{c}\text { Normal (18.50 } \\
\text { to 24.99) }\end{array}$ & 9 & 90.00 & 39 & 97.50 \\
\hline $\begin{array}{c}\text { Overweight (25 } \\
\text { to 29.99) }\end{array}$ & 0 & 0.00 & 0 & 0.00 \\
\hline Obese & 0 & 0.00 & 0 & 0.00 \\
\hline Total & $\mathbf{1 0}$ & $\mathbf{1 0 0}$ & $\mathbf{4 0}$ & $\mathbf{1 0 0}$ \\
\hline
\end{tabular}

Table 12: Table representing the BMI Distribution in relation to CIMT among the Study Population 


\begin{tabular}{|c|c|c|}
\hline BMI Distribution & CIMT $\leq \mathbf{0 . 9} \mathbf{~ m m}$ & CIMT $>\mathbf{0 . 9} \mathbf{~ m m}$ \\
\hline N & 10 & 40 \\
\hline Mean & 20.95 & 21.39 \\
\hline SD & 1.71 & 1.80 \\
\hline P value Unpaired t Test & 0.4846 \\
\hline $\begin{array}{r}\text { Table 13: Statistics representing the BMI Distribution in } \\
\text { relation to CIMT among the Study Population }\end{array}$ \\
\hline \multicolumn{2}{|r}{}
\end{tabular}

Majority of the CIMT $\leq 0.9 \mathrm{~mm}$ Group patients belonged to the normal BMI class interval $(n=9,90 \%)$ with a mean BMI of 20.95. In the CIMT $>0.9 \mathrm{~mm}$ group patients, majority belonged to the same BMI class interval $(n=39,97.50 \%)$ with a mean BMI of 21.39. The association between the study groups and BMI distribution is considered to be not statistically significant since $p>0.05$ as per unpaired $t$ test.

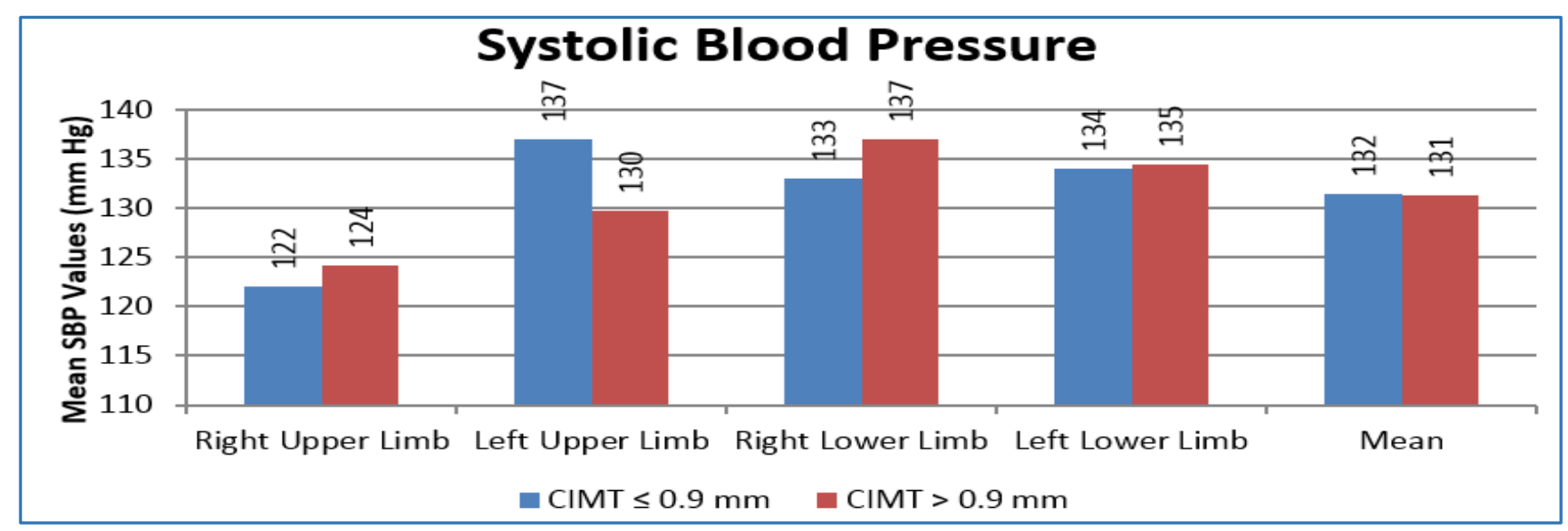

Fig. 9: Bar Diagram representing the Mean Systolic Blood Pressure values among the Study Population

\begin{tabular}{|c|c|c|c|c|c|c|}
\hline \multicolumn{2}{|c|}{ Systolic Blood Pressure } & Right Upper Limb & Left Upper Limb & Right Lower Limb & Left Lower Limb & Mean \\
\hline \multirow{3}{*}{$\mathrm{CIMT} \leq 0.9 \mathrm{~mm}$} & $\mathrm{~N}$ & 10 & 10 & 10 & 10 & 10 \\
\hline & Mean & 122.00 & 137.00 & 133.00 & 134.00 & 131.50 \\
\hline & SD & 11.35 & 9.49 & 9.49 & 5.16 & 5.30 \\
\hline \multirow{3}{*}{ CIMT $>0.9 \mathrm{~mm}$} & $\mathrm{~N}$ & 40 & 40 & 40 & 40 & 40 \\
\hline & Mean & 124.25 & 129.75 & 137.00 & 134.50 & 131.38 \\
\hline & SD & 11.96 & 12.30 & 4.64 & 5.04 & 5.69 \\
\hline \multicolumn{2}{|c|}{$P$ value Unpaired t Test } & 0.5877 & 0.0581 & 0.2241 & 0.7873 & 0.9485 \\
\hline
\end{tabular}

Majority of the CIMT $\leq 0.9 \mathrm{~mm}$ Group patients had a mean SBP of $132 \mathrm{~mm} \mathrm{Hg}$. In the CIMT $>0.9 \mathrm{~mm}$ group, patients had a mean SBP of $131 \mathrm{mmHg}$. The association between the study groups and systolic blood pressure distribution is considered to be not statistically significant since $p>0.05$ as per unpaired t test.

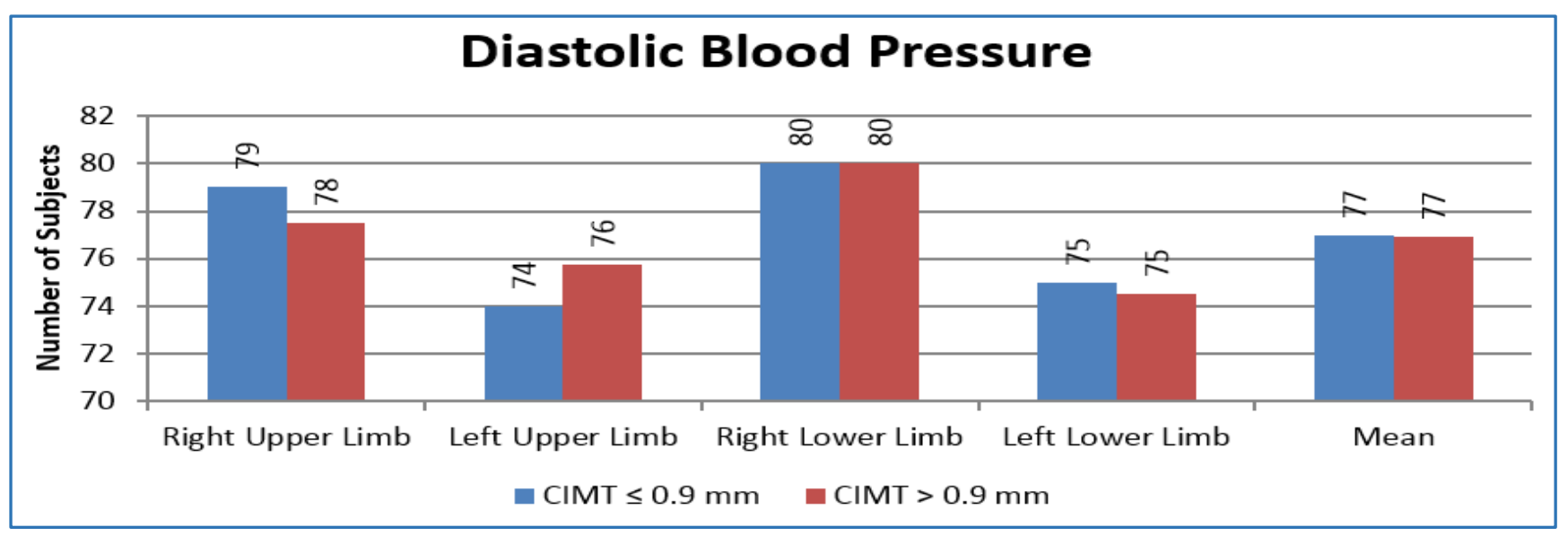

Fig. 10: Bar Diagram representing the Mean Diastolic Blood Pressure values among the Study Population

\begin{tabular}{|c|c|c|c|c|c|c|}
\hline \multicolumn{2}{|c|}{ Diastolic Blood Pressure } & Right Upper Limb & Left Upper Limb & Right Lower Limb & Left Lower Limb & Mean \\
\hline \multirow{3}{*}{$\mathrm{CIMT} \leq 0.9 \mathrm{~mm}$} & $\mathrm{~N}$ & 10 & 10 & 10 & 10 & 10 \\
\hline & Mean & 79.00 & 74.00 & 80.00 & 75.00 & 77.00 \\
\hline & SD & 3.16 & 5.16 & 0.00 & 5.27 & 1.58 \\
\hline \multirow{3}{*}{$\mathrm{CIMT}>0.9 \mathrm{~mm}$} & $\mathrm{~N}$ & 40 & 40 & 40 & 40 & 40 \\
\hline & Mean & 77.50 & 75.75 & 80.00 & 74.50 & 76.94 \\
\hline & SD & 4.39 & 5.01 & 0.00 & 5.04 & 2.80 \\
\hline \multicolumn{2}{|c|}{$P$ value Unpaired $t$ Test } & 0.2329 & 0.3518 & NA & 0.7908 & 0.9262 \\
\hline
\end{tabular}


Majority of the CIMT $\leq 0.9 \mathrm{~mm}$ group patients had a mean DBP of $77 \mathrm{mmHg}$. In the CIMT $>0.9 \mathrm{~mm}$ group, patients had a mean DBP of $77 \mathrm{mmHg}$ The association between the study groups and diastolic blood pressure distribution is considered to be not statistically significant since $p>0.05$ as per unpaired t test.

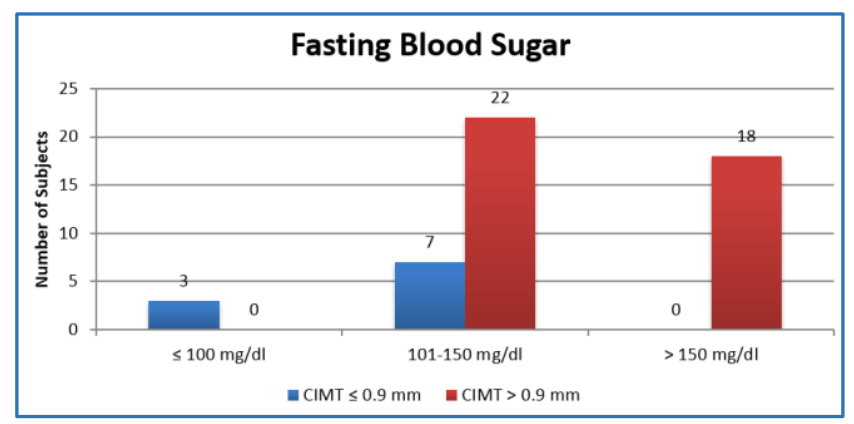

Fig. 11: Bar Diagram correlating the Fasting Blood Sugar values with CIMT among the Study Population

\begin{tabular}{|c|c|c|c|c|}
\hline $\begin{array}{c}\text { Fasting } \\
\text { Blood Sugar }\end{array}$ & $\begin{array}{c}\text { CIMT } \leq \\
\mathbf{0 . 9} \mathbf{~ m m}\end{array}$ & $\%$ & $\begin{array}{c}\text { CIMT }> \\
\mathbf{0 . 9} \mathbf{~ m m}\end{array}$ & $\%$ \\
\hline$\leq 100 \mathrm{mg} / \mathrm{dL}$ & 3 & 30.00 & 0 & 0.00 \\
\hline $\begin{array}{c}101-150 \\
\mathrm{mg} / \mathrm{dL}\end{array}$ & 7 & 70.00 & 22 & 55.00 \\
\hline$>150 \mathrm{mg} / \mathrm{dL}$ & 0 & 0.00 & 18 & 45.00 \\
\hline Total & $\mathbf{1 0}$ & $\mathbf{1 0 0}$ & $\mathbf{4 0}$ & $\mathbf{1 0 0}$ \\
\hline Table 16: Table correlating the Fasting Blood Sugar \\
Values with CIMT among the Study Population \\
\hline
\end{tabular}

\begin{tabular}{|c|c|c|}
\hline $\begin{array}{c}\text { Fasting } \\
\text { Blood Sugar }\end{array}$ & $\begin{array}{c}\text { CIMT } \leq \mathbf{0 . 9} \\
\mathbf{m m}\end{array}$ & $\begin{array}{c}\text { CIMT }>\mathbf{0 . 9} \\
\mathbf{~ m m}\end{array}$ \\
\hline N & 10 & 40 \\
\hline Mean & 105.60 & 148.23 \\
\hline SD & 9.08 & 19.35 \\
\hline P value Unpaired t Test & 0.0000 \\
\hline $\begin{array}{c}\text { Table 17: Statistics correlating the Fasting Blood Sugar } \\
\text { values with CIMT among the Study Population }\end{array}$ \\
\hline
\end{tabular}

\section{RESULTS}

In patients belonging to CIMT $\leq 0.9 \mathrm{~mm}$ group, the mean FBS is $105.60 \mathrm{mg} / \mathrm{dL}$. In CIMT $>0.9 \mathrm{~mm}$ group, the mean FBS is 148.23 $\mathrm{mg} / \mathrm{dL}$. The decreased mean FBS in CIMT $\leq 0.9 \mathrm{~mm}$ group compared to the CIMT $>0.9 \mathrm{~mm}$ group is statistically significant as the $p$ value is 0.0000 as per unpaired t-test indicating a true difference among study groups.

The mean FBS was meaningfully less in CIMT $\leq 0.9 \mathrm{~mm}$ group compared to the CIMT $>0.9 \mathrm{~mm}$ group by $42.63 \mathrm{mg} / \mathrm{dL}$. This significant difference of $29 \%$ decrease in mean FBS in CIMT $\leq 0.9 \mathrm{~mm}$ group compared to the CIMT $>0.9 \mathrm{~mm}$ group is true and has not occurred by chance.

In this study, we can safely conclude that mean fasting blood sugar was significantly and consistently higher in CIMT $>0.9 \mathrm{~mm}$ group compared to the CIMT $\leq 0.9 \mathrm{~mm}$ group. Hence, we can infer that the incidence of CIMT $>0.9 \mathrm{~mm}$ increases with increasing levels of FBS.

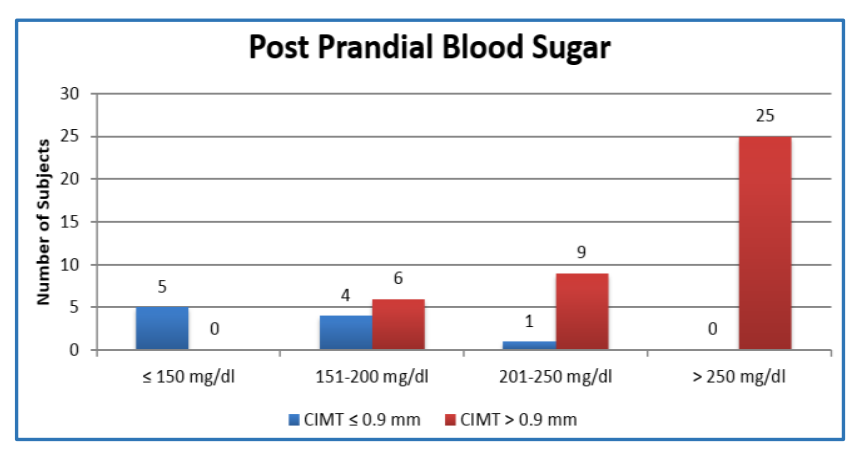

Fig. 12: Bar diagram correlating the Postprandial Blood Sugar values with CIMT among the Study Population

\begin{tabular}{|c|c|c|c|c|}
\hline $\begin{array}{c}\text { Postprandial } \\
\text { Blood Sugar }\end{array}$ & $\begin{array}{c}\text { CIMT } \leq \\
\mathbf{0 . 9} \mathbf{~ m m}\end{array}$ & $\%$ & $\begin{array}{c}\text { CIMT > } \\
\mathbf{0 . 9} \mathbf{~ m m}\end{array}$ & $\%$ \\
\hline$\leq 150 \mathrm{mg} / \mathrm{dL}$ & 5 & 50.00 & 0 & 0.00 \\
\hline $\begin{array}{c}151-200 \\
\mathrm{mg} / \mathrm{dL}\end{array}$ & 4 & 40.00 & 6 & 15.00 \\
\hline $\begin{array}{c}201-250 \\
\mathrm{mg} / \mathrm{dL}\end{array}$ & 1 & 10.00 & 9 & 22.50 \\
\hline$>250 \mathrm{mg} / \mathrm{dL}$ & 0 & 0.00 & 25 & 62.50 \\
\hline \multicolumn{6}{|c|}{ Total } & $\mathbf{1 0}$ & $\mathbf{1 0 0}$ & $\mathbf{4 0}$ & $\mathbf{1 0 0}$ \\
\hline \\
Table 18: Table correlating the Postprandial Blood \\
Sugar Values with CIMT among the Study Population \\
\hline
\end{tabular}

\begin{tabular}{|c|c|c|}
\hline $\begin{array}{c}\text { Postprandial } \\
\text { Blood Sugar }\end{array}$ & CIMT $\leq \mathbf{0 . 9} \mathbf{~ m m}$ & $\begin{array}{c}\text { CIMT }>\mathbf{0 . 9} \\
\mathbf{~ m m}\end{array}$ \\
\hline $\mathrm{N}$ & 10 & 40 \\
\hline Mean & 155.40 & 253.38 \\
\hline SD & 31.26 & 34.28 \\
\hline P value Unpaired t Test & 0.0000 \\
\hline $\begin{array}{c}\text { Table 19: Statistics correlating the Postprandial Blood } \\
\text { Sugar Values with CIMT among the Study Population }\end{array}$ \\
\hline
\end{tabular}

\section{RESULTS}

In patients belonging to CIMT $\leq 0.9 \mathrm{~mm}$ group, the mean PPBS is $155.40 \mathrm{mg} / \mathrm{dL}$. In CIMT $>0.9 \mathrm{~mm}$ group, the mean PPBS is $253.38 \mathrm{mg} / \mathrm{dL}$. The decreased mean PPBS in CIMT $\leq 0.9 \mathrm{~mm}$ group compared to the CIMT $>0.9 \mathrm{~mm}$ group is statistically significant as the $\mathrm{p}$ value is 0.0000 as per unpaired t-test indicating a true difference among study groups.

The mean PPBS was meaningfully less in CIMT $\leq 0.9 \mathrm{~mm}$ group compared to the CIMT $>0.9 \mathrm{~mm}$ group by $97.98 \mathrm{mg} / \mathrm{dL}$. This significant difference of $39 \%$ decrease in mean PPBS in CIMT $\leq 0.9 \mathrm{~mm}$ group compared to the CIMT $>0.9 \mathrm{~mm}$ group is true and has not occurred by chance.

In this study, we can safely conclude that mean postprandial blood sugar was significantly and consistently higher in CIMT $>0.9 \mathrm{~mm}$ group compared to the CIMT $\leq 0.9 \mathrm{~mm}$ group. Hence, we can infer that the incidence of CIMT $>0.9 \mathrm{~mm}$ increases with increasing levels of PPBS. 


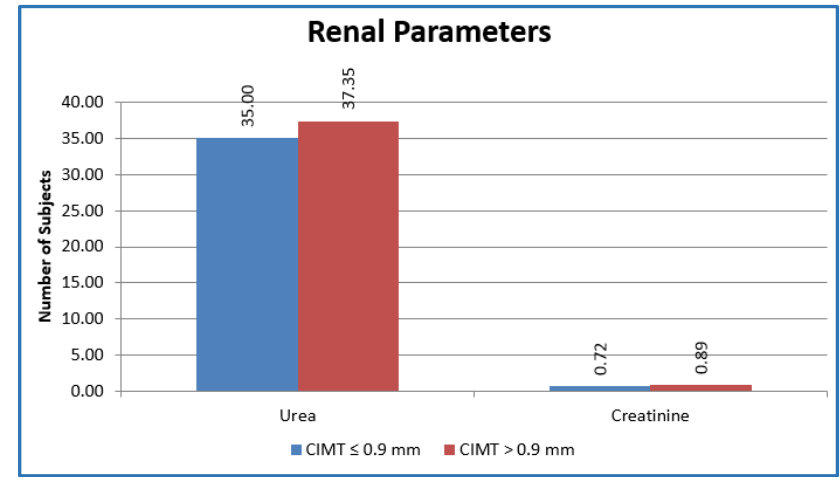

Fig. 13: Bar Diagram correlating the Renal Parameters with CIMT among the study Population

\begin{tabular}{|c|c|c|c|}
\hline \multicolumn{2}{|c|}{ Renal Parameters } & Urea & Creatinine \\
\hline CIMT $\leq 0.9 \mathrm{~mm}$ & $\mathrm{~N}$ & 10 & 10 \\
\cline { 2 - 4 } & Mean & 35.00 & 0.72 \\
\cline { 2 - 4 } & $\mathrm{SD}$ & 3.30 & 0.09 \\
\hline \multirow{2}{*}{ CIMT $>0.9 \mathrm{~mm}$} & $\mathrm{~N}$ & 40 & 40 \\
\cline { 2 - 4 } & Mean & 37.35 & 0.89 \\
\cline { 2 - 4 } & $\mathrm{SD}$ & 3.77 & 0.22 \\
\hline \multicolumn{2}{|c|}{ P value Unpaired t Test } & 0.1489 & 0.2227 \\
\hline \multicolumn{2}{|c|}{$\begin{array}{c}\text { Table 20: Statistics correlating the Renal Parameters } \\
\text { with CIMT among the Study Population }\end{array}$} \\
\hline
\end{tabular}

Majority of the CIMT $\leq 0.9 \mathrm{~mm}$ Group patients had a mean blood urea levels of $35 \mathrm{mg} / \mathrm{dL}$ and mean serum creatinine levels of $0.72 \mathrm{mg} / \mathrm{dL}$. In the CIMT $>0.9 \mathrm{~mm}$ group, patients had a mean blood urea levels of $37.35 \mathrm{mg} / \mathrm{dL}$ and mean serum creatinine levels of $0.89 \mathrm{mg} / \mathrm{dL}$. The association between the study groups and levels of blood urea and serum creatinine is considered to be not statistically significant since $p>0.05$ as per unpaired t test.

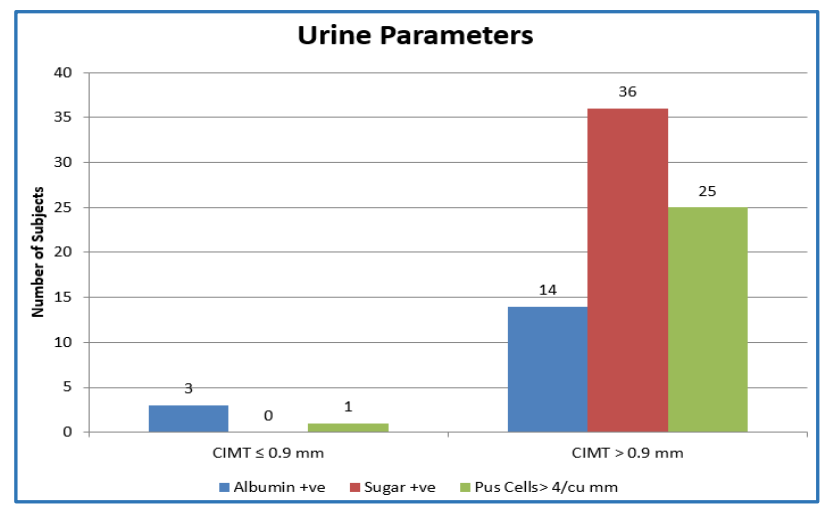

Fig. 14: Bar Diagram correlating the Urine Parameters with CIMT among the Study Population

\begin{tabular}{|c|c|c|c|c|c|}
\hline 导 & 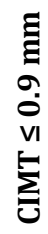 & $\delta^{0}$ & $\begin{array}{l}\Xi \\
\Xi \\
\sigma \\
0 \\
\Lambda \\
\hat{~} \\
\vdots\end{array}$ & $\overbrace{}^{0}$ & 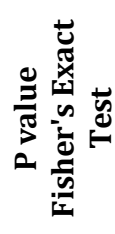 \\
\hline Albumin +ve & 3 & 30.00 & 14 & 35.00 & 0.9999 \\
\hline Sugar +ve & 0 & 0.00 & 36 & 90.00 & 0.3671 \\
\hline $\begin{array}{l}\text { Pus Cells }> \\
4 / \mathrm{cu} \mathrm{mm}\end{array}$ & 1 & 10.00 & 25 & 62.50 & \\
\hline
\end{tabular}

Majority of the CIMT $\leq 0.9 \mathrm{~mm}$ group patients had urine albumin positive $(\mathrm{n}=3,30 \%)$. In the CIMT $>0.9 \mathrm{~mm}$ group, patients mainly had urine sugar positive $(n=36,90 \%)$. The association between the study groups, urine test parameters are considered to be not statistically significant since $p>0.05$ as per unpaired $t$ test.

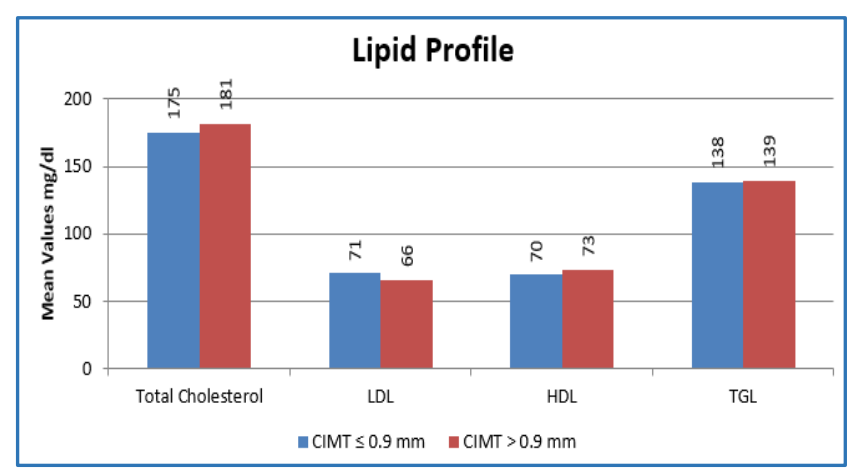

Fig. 15: Bar Diagram correlating Lipid Profile with CIMT among the Study Population

\begin{tabular}{|c|c|c|c|c|c|}
\hline \multicolumn{2}{|c|}{$\begin{array}{c}\text { Lipid } \\
\text { Profile }\end{array}$} & $\begin{array}{c}\text { Total } \\
\text { Cholest } \\
\text { erol }\end{array}$ & LDL & HDL & TGL \\
\hline \multirow{2}{*}{$\begin{array}{c}\text { CIMT } \leq \\
0.9 \mathrm{~mm}\end{array}$} & $\mathrm{~N}$ & 10 & 10 & 10 & 10 \\
\cline { 2 - 6 } & Mean & 175.40 & 70.50 & 69.50 & 138.20 \\
\cline { 2 - 6 } & $\mathrm{SD}$ & 12.55 & 4.14 & 4.09 & 4.76 \\
\hline \multirow{2}{*}{$\begin{array}{c}\text { CIMT }> \\
0.9 \mathrm{~mm}\end{array}$} & $\mathrm{~N}$ & 40 & 40 & 40 & 40 \\
\cline { 2 - 6 } & Mean & 181.40 & 65.65 & 73.43 & 139.18 \\
\cline { 2 - 6 } & $\mathrm{SD}$ & 11.41 & 8.13 & 7.06 & 9.94 \\
\hline \multirow{2}{|c|}{$\begin{array}{c}\text { P value } \\
\text { Unpaired t Test }\end{array}$} & 0.1919 & 0.513 & 0.0705 & 0.6571 \\
\hline Table 22: Statistics correlating Lipid Profile with CIMT \\
among the Study Population \\
\hline
\end{tabular}

Majority of the CIMT $\leq 0.9 \mathrm{~mm}$ Group patients had a mean total cholesterol levels of $175.40 \mathrm{mg} / \mathrm{dL}$, mean LDL levels of $70.50 \mathrm{mg} / \mathrm{dL}$, mean HDL levels of $69.50 \mathrm{mg} / \mathrm{dL}$ and mean TGL levels of $138.20 \mathrm{mg} / \mathrm{dL}$. In the CIMT $>0.9 \mathrm{~mm}$ group patients had a mean total cholesterol levels of $181.40 \mathrm{mg} / \mathrm{dL}$, mean LDL levels of $65.65 \mathrm{mg} / \mathrm{dL}$, mean HDL levels of $73.43 \mathrm{mg} / \mathrm{dL}$ and mean TGL levels of $139.18 \mathrm{mg} / \mathrm{dL}$. The association between the study groups and lipid profile parameters is considered to be not statistically significant since $p>0.05$ as per unpaired $t$ test.

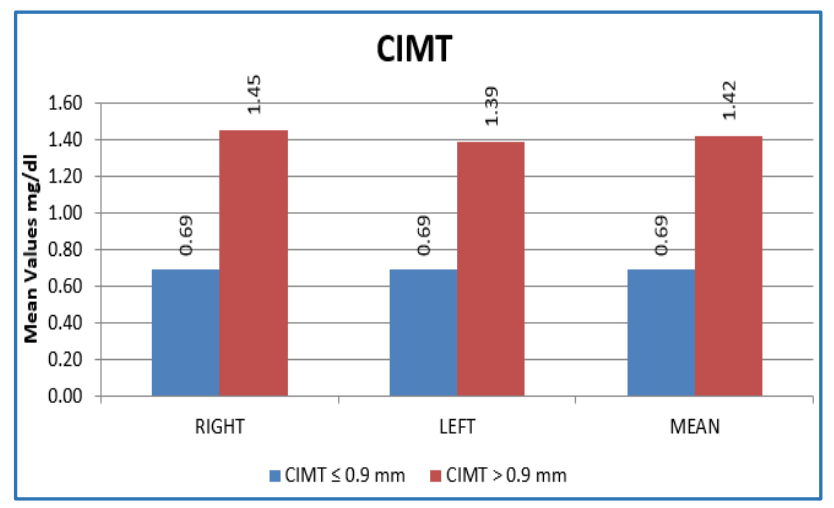

Figure 16: Bar Diagram depicting the Mean CIMT Values on both Sides 


\begin{tabular}{|l|c|c|c|c|}
\hline CIMT & RIGHT & LEFT & MEAN \\
\hline \multirow{3}{*}{ CIMT $\leq 0.9 \mathrm{~mm}$} & $\mathrm{~N}$ & 10 & 10 & 10 \\
\cline { 2 - 5 } & Mean & 0.69 & 0.69 & 0.69 \\
\cline { 2 - 5 } & $\mathrm{SD}$ & 0.11 & 0.11 & 0.11 \\
\hline \multirow{3}{*}{ CIMT > 0.9 mm } & $\mathrm{N}$ & 40 & 40 & 40 \\
\cline { 2 - 5 } & Mean & 1.45 & 1.39 & 1.42 \\
\cline { 2 - 5 } & $\mathrm{SD}$ & 0.27 & 0.22 & 0.23 \\
\hline Table 23: Statistics of the Mean CIMT Values \\
on both Sides
\end{tabular}

\begin{tabular}{|c|c|c|c|}
\hline \multirow{2}{*}{$\begin{array}{l}\text { Independent } \\
\text { Variables }\end{array}$} & \multicolumn{3}{|c|}{ CIMT $>0.9 \mathrm{~mm}$} \\
\hline & $\begin{array}{l}\text { Odds } \\
\text { Ratio }\end{array}$ & $\begin{array}{l}\text { 95\% Confidence } \\
\text { Interval }\end{array}$ & $P$ value \\
\hline Age $>50$ years & 4.36 & $0.56-33.74$ & 0.158 \\
\hline Gender - Male & 1.91 & $0.33-38.4$ & 0.216 \\
\hline $\begin{array}{c}\text { Duration of } \\
\text { Diabetes }>5 \\
\text { years }\end{array}$ & 10.18 & $1.09-94.73$ & $0.042^{*}$ \\
\hline Smoking & 3.04 & $1.33-6.95$ & $0.008^{*}$ \\
\hline Alcohol Intake & 4.29 & $1.12-16.52$ & 0.039* \\
\hline $\begin{array}{c}\mathrm{FBS}>150 \\
\mathrm{mg} / \mathrm{dL}\end{array}$ & 1.16 & $1.17-12.49$ & $0.041^{*}$ \\
\hline $\begin{array}{c}\mathrm{PPBS}>250 \\
\mathrm{mg} / \mathrm{dL}\end{array}$ & 3.58 & $1.15-11.13$ & $0.043^{*}$ \\
\hline
\end{tabular}

Multivariate logistic Regression model for statistically Significant Predictor of Immediate Adverse Event

\section{RESULTS}

\section{Multivariate Analysis Demonstrated that}

- The risk of developing CIMT $>0.9 \mathrm{~mm}$ in patients with duration of diabetics $>5$ years is 10.18 times significantly more than patients with duration of diabetics $<5$ years. It is statistically significant with a p-value of 0.0042 .

- The risk of developing CIMT>0.9 mm in patients who smoke is 3.04 times significantly more than in nonsmokers. It is statistically significant with a p-value of 0.008 .

- The risk of developing CIMT>0.9 mm in patients who consume alcohol is 4.29 times significantly more than patients without alcohol intake. It is statistically significant with a $\mathrm{p}$ value of 0.0039 .

- The risk of developing CIMT $>0.9 \mathrm{~mm}$ in patients with FBS $>150 \mathrm{mg} / \mathrm{dL}$ is 1.16 times significantly more than patients with FBS $<150 \mathrm{mg} / \mathrm{dL}$. It is statistically significant with a $\mathrm{p}$ value of 0.0041 .

- The risk of developing CIMT $>0.9 \mathrm{~mm}$ in patients with PPBS $>250 \mathrm{mg} / \mathrm{dL}$ is 3.58 times significantly more than patients with PPBS $<250 \mathrm{mg} / \mathrm{dL}$. It is statistically significant with a p value of 0.0043 .

\section{DISCUSSION}

- We did not find any significant association between age and CIMT, the mean age group was found to be almost same.

- $\quad$ There was no significant association between CIMT and gender distribution.
- $\quad$ CIMT was significantly associated more with duration of diabetes (as the duration increased).

- Smokers were found to be at higher risk of increase in CIMT than non-smokers.

- Though the distribution of alcohol intake was equal among both the age groups, but CIMT was more significant among patients with diabetes and alcoholism. As our study group volume is small, we could not prove the exact association between CIMT and alcohol intake.

- In our study population, BMI didn't show any significant association.

- Blood pressure was not found to be statistically significant in our study population.

- Patients with higher fasting and postprandial blood sugar value showed significant association with CIMT values.

- Urine routine, renal parameters and lipid profile didn't show any significant correlation with carotid IMT in our study.

As compared to the cited, original articles which showed direct relation between diabetes and CIMT, our study population had around $80 \%$ diabetic patients with significant carotid CIMT values. CIMT was more significant with increase in the duration of diabetes, altered fasting and postprandial glycaemic status.(2) This was similar to the original study article. CIMT greater than $0.9 \mathrm{~mm}$ was an individual marker of generalised atherosclerosis. Patients with these values are at higher risk for future cardiovascular events and newer or recurrent ischaemic strokes. $80 \%$ of our study group comes under this high risk category. Significant increase in carotid IMT was found with patients who smoke and consume alcohol. Possible explanation for this difference may be related to limited sample size of the study and ethnicity of the study subjects.

\section{CONCLUSION}

This study concludes that even in the absence of smoking and alcohol intake, and in the presence of normotension and normal lipid profile, independently type 2 DM was found to be associated with carotid IMT values than other components. Further workup and prospective studies are needed with regards to

1. To predict the trend of future cardiovascular events like CAD and ischaemic strokes.

2. Regression of CIMT with management of type 2 DM patients.

\section{REFERENCES}

1. Sibal L, Agarwal SC, Home PD. Carotid intima-media thickness as a surrogate marker of cardiovascular disease in diabetes. Diabetes Metabolic Syndrome Obes 2011;4:23-34.

2. Zhao XH, Xu ZR, Zhang $Q$ et al. Effect of intensive multifactorial treatment on the intima-media thickness of large arteries in patients with new-onset type 2 diabetes mellitus. Journal Zhejiang University Science B 2012;13(5):378-85. 